\title{
A STUDY OF PRE-SERVICE ELT TEACHERS' CULTURAL INTELLIGENCE AND ITS RELATIONSHIP WITH METACOGNITIVE, COGNITIVE, MOTIVATIONAL, AND BEHAVIORAL CULTURAL INTELLIGENCE ${ }^{i}$
}

\author{
Aihemaituoheti Wujiabudula ${ }^{1 i i}$, \\ Çiğdem Karatepe ${ }^{2}$ \\ 1Uskudar University, \\ Turkey \\ ${ }^{2}$ Bursa Uludag University, \\ Turkey
}

\begin{abstract}
:
This study aimed to examine different aspects of ELT teachers' cultural intelligence, namely: "meta-cognitive", "cognitive", "motivational" and "behavioral" cultural intelligence. To this end, the current study aspired to examine a group of pre-service English teachers to measure their cultural intelligence. It also aimed to research the student teachers' cultural intelligence in terms of their gender, age, native tongue, their experience of traveling abroad, English proficiency, years of learning English, and finally, their grades. A total of 148 participants from various English language teaching departments participated in this study. A questionnaire was used to elicit the student teachers' cultural intelligence. The SPSS 24 software program was used to perform statistical analysis, and specifically, factor analysis, the tests of reliability and normality, correlation analysis, and non-parametric tests were conducted to determine and analyze the statistical results of this study. The findings suggested that, first of all, all student English teachers' overall degree of cultural intelligence was considerably higher than that of the average person (in Turkey). However, the student English teachers' cultural intelligence showed a statistically significant difference which related to their overseas experience, and to their proficiency in English. Moreover, the participants' metacognitive intelligence showed statistical differences in terms of their age. However, cognitive, motivational, and behavioral intelligence and cultural intelligence showed no statistical difference due to age. As for the participants' proficiency, it was determined that metacognitive, motivational, behavioral, and cultural intelligence revealed statistically significant differences, whereas cognitive intelligence showed no statistically
\end{abstract}

\footnotetext{
İNGILIZCE ÖĞRETMEN ADAYLARIN KÜLTÜREL ZEKÂSI VE ÜST BILIŞSEL, BILIŞSEL, MOTIVASYONEL VE DAVRANIŞSAL KÜLTÜREL ZEKÂLARI ARASINDAKI ILIŞKI ÜZERINE BIR ÇALIŞMA

ii Correspondence: email: alan.w@uskudar.edu.tr
} 
significant difference. The findings were discussed and implications for the future research were given along with limitations found in the study.

Keywords: culture, cultural intelligence, pre-service ELT Teachers

\section{Özet:}

Bu çalışma, İngilizce öğretmen adaylarının kültürel zekasını ve "meta-bilişsel", "bilişsel", "motivasyonel" ve "davranışsal" kültürel zekasını incelemeyi amaçlamıştır. Bu amaçla, bu çalışma bir grup İngilizce öğretmenini kültürel zekalarını ölçmek için incelemeyi amaçlamıştır. Ayrıca öğrenci öğretmenlerin kültürel zekasını cinsiyet, yaş, anadilleri, yurtdışına seyahat deneyimleri, İngilizce yeterlilikleri, İngilizce öğrenme süreleri ve son olarak ingilizce öğretmenl adaylarının şu anki sıfıları açısından araştırmayı amaçlamıştır. $\mathrm{Bu}$ çalışmaya çeşitli İngilizce öğretmenliği bölümlerinden toplam 148 katılımcı katılmıştır. Öğrenci öğretmenlerinin kültürel zekasını ortaya koymak için bir anket kullanılmıştır. Bu çalışmanın istatistiksel sonuçlarını belirlemek ve istatistiksel analiz yapmak amaciyla SPSS 24, özellikle faktör analizi, güvenilirlik ve normallik testi, korelasyon analizi ve parametrik olmayan testler kullanılmıştır. Bulgular, her şeyden önce, İngilizce öğrenci öğretmenlerinin kültürel zekâ derecesinin önemli ölçüde daha yüksek olduğunu göstermiştir. Ancak, İngilizce öğrenci öğretmenlerinin kültürel zekâsı, yurtdışı seyahat deneyimleri ve ELT öğretmen adaylarının İngilizce yeterlilikleriyle ilgili istatistiksel olarak anlamlı bir farklılık göstermiştir. Ayrıca, katılımcıların meta-bilişsel zekâları yaşlarına göre istatistiksel farklılıklar göstermiştir. Bununla birlikte, bilişsel, motivasyonel ve davranışsal kültürel zekâ katılımcıların yaşı açısından istatistiksel olarak anlamlı bir farklılık göstermemiştir. Katılımcıların İngilizce yeterliliğine gelince, üst bilişsel, motivasyonel, davranışsal ve kültürel zekanın önemli farklılıklar gösterdiğini, bilişsel zekanın istatistiksel olarak anlamlı bir fark göstermediğini gösterilmiştir. Çalışmada bulunan sınırlamalarla birlikte gelecekteki araştırmalar için tartışma ve çıkarımlar verilmiştir.

Anahtar sözcükler: İngilice eğitiminde kültür, İngilizce öğretmen adayları, kültürel zekâ

\section{Introduction}

Over the past forty or fifty years, developments in technology have brought significant changes to every field of education. The availability of technology and accessibility of social media websites have also influenced people's attitudes towards foreign countries, especially their culture.

Political conflict between nations, global terrorism, and the refugee crisis are also significant factors which have been affecting peoples' acknowledgment of different cultures. It is assumed that, in their use of a second language, ELT students are less ethnocentric since they are more likely to have exposure to the foreign, dissimilar cultures, and an ELT students are believed to be more tolerant than others because the 
ELT students are more widely exposed to cultural contexts due to the nature of their department.

Many researchers around the world have put their primary focus on main competences in second language teaching (speaking, listening, reading, and writing). Nevertheless, the significance of culture and teaching culture (global, target, native) has been somewhat ignored, since it is argued whether culture should be taught or not.

However, a growing number of exchange students in state and private universities has given students opportunities, especially ELT students, to enter into relationships, and exchange information and cultural knowledge with each other. Examining the impact of these trends on students' attitudes towards different cultures is believed to be extremely vital. As foreign language teachers have an important role in spreading cultural knowledge to motivate their future English learners to be more culturally competent, their being more tolerant of other cultures is important. Therefore, the importance of gathering more information on student teachers' cultural intelligence (CQ) is shown clearly. When we have foreign language teachers who possess a substantial degree of cultural intelligence, it is believed that racism and prejudice can be eliminated via teaching culture and acknowledging cultural enrichment. Therefore, the current study aimed to investigate the ELT teachers' levels of agreement towards cultural intelligence and differences in CQ in terms of age, gender, proficiency in English, years of learning English, and overseas experience.

This current research will provide educators with the necessary information to prepare course material to equip student teachers to use their cultural knowledge and awareness. Thus, promoting cultural intelligence in pre-service ELT teachers enables these teachers to be capable of alleviating cultural conflict and minimizing incompatibility in cultural interaction (Kim, 1992).

\section{Literature review}

Abundant illustrations are found in the literature in terms of the definition of cultural intelligence and its sub-factors (Earley \& Ang, 2003; Ang \& Van Dyne, 2008; Stemberg \& Detterman, 1986; Schmidt \& Hunter, 2000; Stemberg et al., 2000; Thorndike \& Stein, 1937; Cameli, 2003). Earley \& Ang (2003) considered "cultural intelligence" to be the competence of being able to operate and function effectively in a diverse cultural context. Thomas and Inkson (2003) also conceptualized the idea of "cultural intelligence" in that it is believed to be the multidimensional competence consisting of intercultural knowledge, consciousness towards different cultures, and several skills expressed behaviorally (Thomas \& Inkson, 2003). According to Risager (2006), it should not be forgotten that certain elements are significant. These factors of cultural intelligence include enculturation, acculturation, and deculturation.

First, "enculturation," which includes the acquisition of an individual's native culture. Second, "acculturation," which represents the procedure for learning a culture that is different from one's own. Thirdly, "deculturation," which is isolation from the 
native culture because of the influence of a foreign culture (Risager, 2006). Brislin (1981) also mentioned two meanings of "cultural intelligence." As reported by Brislin, "cultural intelligence" consists of adaptation to other cultural matters and rules of dissimilar cultures. Moreover, it also includes intelligence or competence in a particular culture.

Many measurement tools that can be related to one or several factors of CQ can be found in the literature. However, the more recent definitions of CQ state that it is composed of four different dimensions, namely, "meta-cognitive $C Q$ ", "cognitive $C Q$ ", "motivational CQ", and "behavioral CQ" (Thomas \& Inkson, 2004; Earley and Mosakowski 2004; Earley and Ang, 2003; Ang and Van Dyne, 2008; Brislin, Worthley, \& MacNab, 2006).

Metacognitive CQ: metacognitive cultural intelligence is connected with consciousness, organization, and control. It comprises an individual's experience of a different culture or the intercultural consciousness during the interaction between different cultures (Erez et al., 2013).

Cognitive CQ: cognitive cultural intelligence addresses an individual's' familiarity with similar or different aspects present in socioeconomic norms, and religious orientation of different cultures. Cognitive, cultural intelligence reflects the knowledge structure and features of dissimilar cultures. Individuals who possess a higher level of cultural intelligence acknowledge the convergence and divergence of other cultures (Brislin, Worthley, \& MacNab, 2006).

Motivational CQ: this represents the desire to learn about other cultures. It is related to an individuals' stamina to be willing to communicate with people from other cultures. Self-efficacy has a significant role in motivational cultural intelligence.

Behavioral CQ: behavioral cultural intelligence is linked to an individual's alteration of verbal or non-verbal behavior in an intercultural context used when communicating with different people from dissimilar cultures (Dyne, Ang, \& Livermore, 2009; Keung, 2011).

Numerous studies have been conducted on CQ in terms of participants' study abroad experience, proficiency in English, gender, etc. (Morrel, Ravil, Ramsey, \& Ward, 2013; Wood, Heather, \& St.Peters, 2014; Lee \& Sukoco, 2010; Crowne \& Engle, 2014; Khodaday \& Ghahari, 2012; Rachmawaty, Akil, \& Dollah, 2018; Markum, 2017; Khodaday \& Ghahari, 2012). One study showed that students' cultural intelligence improved after short-term stays in foreign countries. It suggested that the students' cultural intelligence revealed significant improvement not only in the overall level of cultural intelligence but also in their metacognitive CQ, cognitive CQ, motivational CQ and behavioral CQ (Rustambekov \& Mohan, 2017). The same study showed that students' CQ did not show any statistical difference in terms of the participants' ages. Several studies also revealed the significance of time spent in foreign countries for the improvement of participants' CQ (Dwyer \& Mary, 2004; Dwyer, Mary, \& Courtney K. Peters, 2004; Holoviak, Verney, Winter, \& Holoviak, 2019; Barkley, 2009; Gmelch, 1997; Williams \& Best, 2014; McCrea \& Z. Yin, 2012; Morrel, Ravil, Ramsey, \& Ward, 2013). Another study also suggested that even the short period of a cultural tour showed a 
significant relationship between travel and the participants' metacognitive $C Q$, cognitive $C Q$, and motivational CQ. However, no significant statistical difference was found between a short-term cross-cultural tour and behavioral CQ (Wood, Heather, \& St. Peters, 2014; Lee \& Sukoco, 2010; Crowne \& Engle, 2014).

There are also some studies that suggested traveling abroad did not influence the students' cultural intelligence. On the contrary, participants who had no experience of traveling experience to foreign countries showed higher CQ (Khodaday \& Ghahari, 2012). On the other hand, Robert \& Bariana (2016) investigated whether the choice of the country-influenced the learners' CQ. At one of the universities in the USA, the results showed that having the experience of travel to foreign countries impacted the learners' $\mathrm{CQ}$ and that the choice of countries did matter. It was interesting to note that the study also found that learners who traveled to non-Anglo-Saxon countries developed a higher level of cultural intelligence.

The role of language proficiency in determining the CQ level has also been looked at. The results of various studies reported conflicting findings. For example, Rachmawaty et al. (2018) found that proficiency and CQ did not correlate statistically (Rachmawaty, Akil, \& Dollah, 2018). Similarly, Markum (2017) found no predictive relationship between participants' cultural intelligence and language proficiency, whereas Taguchi (2007) also found a positive relationship between general language proficiency and CQ in the Japanese context (Taguchi, 2007). On the other hand, Fatemi \& Etminan (2012) also found that CQ was negatively correlated with participants' proficiency.

However, another study reported the opposite results, which suggested that proficiency in English could promote students' cultural intelligence (Robledo-Ardila et al., 2016). Other researchers attempted to determine which kind of language skills proficiency would play a more dominant role concerning CQ. For instance, Ghonsooly \& Golparvar (2013): found that writing competence had a significant effect on CQ (Ghonsooly \& Shalchy, 2013; Ghonsooly \& Sistani, 2015).

The relationship between gender and cultural intelligence has also been studied by numerous scholars (Khodaday \& Ghahari, 2012; Aziz, Fatemi, Pishghadam, \& Ghapanchi, 2015). One of the studies conducted concentrated on the validation of Persian CQ concerning participants' gender, tuition, international travel experience, and places where participants stayed. The results of the study suggested that the female participants' metacognitive CQ was higher than that of the male students (Khodaday \& Ghahari, 2012). Azizi et al. also conducted a study into Iranian EFL students' cultural intelligence and their home culture connection. The study found that ELT learners' CQ showed a statistically meaningful difference between males and females, which indicated that male students' CQ was higher than the female participants. The same study also supported that gender showed no statistically significant relationship with participants' CQ (Aziz, Fatemi, Pishghadam, \& Ghapanchi, 2015).

No study was found about the impact of the period spent in foreign countries and its relationship with CQ. Academic success was also another new variable to be examined since it is assumed that the higher grade they have, the higher CQ ELT pre-service 
teachers will demonstrate. Also, examining the relationship between the sub-factors of CQ has been widely researched in many fields. However, few studies have been found concerning the CQ of pre-service ELT teachers. Thus, researching pre-service ELT teachers' CQ is of great importance in terms of the second language acquisition process.

\section{Research questions}

To this end, the research questions below were generated:

1. What are the pre-service ELT teachers' levels of cultural intelligence?

2. Do the pre-service ELT teachers' levels of cultural intelligence vary according to the following factors?
a. Age
b. Gender
c. Years of learning English
d. Perceived proficiency in English
e. Overseas experience
f. University grade

3. What is the relationship between the pre-service ELT teachers' cultural intelligence and the following dimensions of cultural intelligence?
a. "metacognitive",
b. "cognitive",
c. "motivational",
d. "behavioral".

\section{Method}

The current study aimed to measure the pre-service ELT teachers' CQ and to investigate whether their CQ showed any statistical difference in terms of their age, gender, proficiency in English, years of learning English, university grade, and overseas experience. Therefore, in this research, a quantitative research method was introduced, using the medium of a questionnaire.

The process consisted of two stages. The first part of the questionnaire included items that aimed to gather demographic information on the pre-service ELT teachers: gender, age, proficiency in English, overseas experience, grades at universities, and years of learning English. The second section included 20 questions of the Cultural Intelligence Scale, which were taken from Van Dyne \& Ang (2008). The questionnaire items were related to the four factors: "cognitive", "metacognitive", "motivational" and "behavioral" cultural intelligence." Items 1 to 4 aimed to collect data on metacognitive $C Q$, items 6-10 aimed to elicit information on cognitive CQ, items 10 to 15 focused on motivational CQ, and the last four items aimed to gain information on behavioral CQ. A five-point Likert scale was used; 1 represented "strongly disagree", 2 expressed "disagree", 3 meant "neutral", 4 stood for "agree", and 5 showed "strongly agree". 
The target population of this research was pre-service ELT teacher who were continuing their ELT education at different universities in Turkey. The Cultural Intelligence Scale was used (Van Dyne \& Ang (2008).

The participants first provided their informed consent about taking part in the research, and participation was voluntary. Then, 200 questionnaires were distributed, and no interruption was made while the pre-service ELT teachers answered the questionnaire. There were 148 participants in this sample. After the collection of the research questionnaires, all the questionnaires were numbered randomly and entered into the SPSS 24 software.

Concerning the data analysis, the SPSS 24 software program was used for statistical tests. First of all, a test of reliability was conducted. Then a test of normality was performed to determine whether the collected data showed normal distribution or not. The results of the test of reliability are shown in Table 1, and it showed a high Cronbach's alpha coefficient $(0.855)$, which indicated that the data were highly reliable. The test of normality (Table 2) showed that the collected data were not normally distributed; therefore, non-parametric tests were conducted in order to compare the mean differences between the different variables.

\section{Results}

Before the statistical tests, factor analysis was conducted to check whether the data produced the same factors as the original scale. Then the correlation between each factor was examined to enable the production of more reliable findings and results for the study.

Table 1: Reliability Statistics

\begin{tabular}{|l|l|c|c|c|c|}
\hline & & $\mathbf{N}$ & $\mathbf{\%}$ & Cronbach's Alpha & N \\
\hline & Valid & 148 & $100 \%$ & & \\
\hline Case & Excluded & 0 & 0 & & \\
\hline & Total & 148 & 100 & $\mathbf{0 . 8 5 2}$ & 20 \\
\hline
\end{tabular}

Table 2: Test of Normality

\begin{tabular}{|l|c|c|c|c|c|c|}
\hline & \multirow{2}{*}{ Mean } & \multirow{2}{*}{ Variance } & \multirow{2}{*}{ Std. } & \multicolumn{3}{|c|}{ Shapiro-Wilk } \\
\cline { 5 - 7 } & & & & Statistics & Df & Sig. \\
\hline Total Scale & 74.17 & 82.781 & 0.098 & 0.977 & 148 & $\mathbf{0 . 0 1 5}$ \\
\hline
\end{tabular}

Sig. $>0.05$.

Since the data collected at state universities in Turkey have a different context, factor analysis was conducted to check whether the data collected showed the same factors or not. First of all, the Kaiser-Meyer-Olkin (KMO) measure and Bartlett's test were conducted to ensure the data were suitable for conducting factor analysis. Table 3 shows that the KMO measure of sampling adequacy was considered acceptable to proceed with factors analysis $(0.778$, Sig. $<0.05)$. 
Table 3: KMO and Bartlett's Test

\begin{tabular}{|l|l|c|}
\hline \multicolumn{2}{|l|}{ Kaiser-Meyer-Olkin Measure of Sampling Adequacy } & 0.778 \\
\hline Bartlett's Test of Sphericity & Approx. Chi-Square & 1219.313 \\
\hline & Df & 190 \\
\hline & Sig. & $\mathbf{0 . 0 0 0}^{*}$ \\
\hline
\end{tabular}

Sig. $<0.05$

According to Table 4, it can be seen that there were four factors were generated from the factor analysis. The first factor explained the almost $28 \%$ of aggregate data. The second factor explained almost $14 \%$ of the data collected. The third factor explained only $9 \%$ of the total data collected. Finally, the last factor explained only $7 \%$ of the total data. According to Table 5, it can be reported that behavioral CQ obtained the highest mean among all the factors of CQ. The second highest mean is for motivational CQ, and metacognitive CQ also shows a higher mean compared to the factor which had the least mean score, cognitive CQ.

Table 4: Total Variance Explained

\begin{tabular}{|l|c|c|c|c|c|c|}
\hline & \multicolumn{3}{|c|}{ Extraction Sums of Squared Loadings } & \multicolumn{3}{c|}{ Rotation Sum of Squared Loadings } \\
\hline Component & Total & (\%) Variance & Cumulative \% & Total & Variance (\%) & Cumulative \% \\
\hline 1 & 5.489 & 27.447 & 27.447 & 3.209 & 16.045 & 16.045 \\
\hline 2 & 2.742 & 13.709 & 41.156 & 3.170 & 15.848 & 31.894 \\
\hline 3 & 1.769 & 8.846 & 50.002 & 2.835 & 14.176 & 46.070 \\
\hline 4 & 1.417 & 7.084 & 57.085 & 2.203 & 11.016 & 57.085 \\
\hline
\end{tabular}

It can be clearly seen that the data collected for this research produced the same number of factors as the original CQ scale. Accordingly, it can also be suggested that the collected data explained total data variance. In ranking these factors, from highest to lowest, we find behavioral $C Q$, followed by motivational $C Q$, metacognitive $C Q$, and cognitive $C Q$.

Table 5: Factor Analysis: Rotated Component Matrix

\begin{tabular}{|l|l|l|l|l|l|}
\hline Factors & Items & $\mathbf{1}$ & $\mathbf{2}$ & $\mathbf{3}$ & $\mathbf{4}$ \\
\hline Metacognitive CQ & 4 & $\mathbf{0 . 6 7 1}$ & & & \\
\hline \multirow{5}{*}{ Cognitive CQ } & Item1 & 0.803 & & & \\
\hline & Item2 & 0.640 & & & \\
\hline & Item3 & 0.777 & & & \\
\hline & Item4 & 0.465 & & & \\
\hline & 6 & & $\mathbf{0 . 6 7 0}$ & & \\
\hline \multirow{5}{*}{ Motivational CQ } & Item5 & & 0.554 & & \\
\hline & Item6 & & 0.487 & & \\
\hline & Item7 & & 0.710 & & \\
\hline & Item8 & & 0.819 & & \\
\hline & Item9 & & 0.776 & & \\
\hline & Item10 & & 0.679 & & \\
\hline \multirow{5}{*}{} & 5 & & & $\mathbf{0 . 6 8 7}$ & \\
\hline & Item11 & & & 0.629 & \\
\hline & Item12 & & & 0.854 & \\
\hline
\end{tabular}




\begin{tabular}{|l|l|l|l|l|l|}
\hline \hline \multirow{5}{*}{ Behavioral CQ } & Item13 & & & 0.797 & \\
\hline & Item14 & & & 0.689 & \\
\hline & Item15 & & & 0.464 & \\
\hline \multirow{5}{*}{} & 5 & & & & $\mathbf{0 . 7 5 5}$ \\
\hline \multirow{5yyyy}{*}{} & Item16 & & & & 0.637 \\
\hline & Item17 & & & & 0.784 \\
\hline & Item18 & & & & 0.821 \\
\hline & Item19 & & & & 0.761 \\
\hline & Item20 & & & & 0.774 \\
\hline
\end{tabular}

Tables 6 and 7 illustrated the overall degree of pre-service ELT teachers' CQ. In order to examine the frequency and rating of their $C Q$, descriptive statistics and frequency analysis were conducted. Table 6 demonstrates that the overall degree of participants' CQ was considerably high. It can be seen in Table 6 that the participants appeared to have a high level of $C Q$ in terms of motivational CQ $(M=4.02)$, metacognitive $C Q(M=3.875)$, and behavioral CQ $(M=3.832)$, and cognitive CQ $(M=3.21)$. While participants showed a higher level of agreement in motivational $C Q$, metacognitive $C Q$, and behavioral $C Q$, they showed a medium level of agreement in cognitive CQ.

In terms of the pre-service ELT teachers' overall degree of CQ, it can be seen from Table 7 that $75 \%$ of participants demonstrated a high level of CQ, while $25 \%$ of them showed a medium level of agreement. To conclude, our participants' CQ was considerably high. Moreover, no questionnaire item received a low level of from participants.

It can also be reported that the pre-service ELT teachers' motivational CQ was the highest contributing factor in their CQ. The second highest contributing factor was metacognitive $C Q$, and the third-highest contributing factor was behavioral CQ. It can also be reported that the least contributing factor was cognitive CQ. However, cognitive CQ demonstrated a medium level of CQ compared to meta-cognitive, motivational, and behavioral CQ.

Table 6: Pre-service ELT Teachers' Degree of Cultural Intelligence

\begin{tabular}{|l|l|c|c|c|c|}
\hline Factor & Items & Mean & Std. & $\mathbf{N}$ & Degree of CQ \\
\hline \multirow{5}{*}{ Meta-cognitive CQ } & $\mathbf{4}$ & $\mathbf{3 . 8 7 5}$ & & $\mathbf{1 4 8}$ & High \\
\cline { 2 - 6 } & Item1 & 3.92 & 0.885 & 148 & High \\
\cline { 2 - 6 } & Item2 & 3.78 & 0.763 & 148 & High \\
\cline { 2 - 6 } & Item3 & 3.85 & 0.786 & 148 & High \\
\cline { 2 - 6 } & Item4 & 3.95 & 0.811 & 148 & High \\
\hline \multirow{5}{*}{ Cognitive CQ } & $\mathbf{6}$ & $\mathbf{3 . 2 1}$ & & $\mathbf{1 4 8}$ & Medium \\
\cline { 2 - 6 } & Item5 & 2.99 & 1.013 & 148 & Medium \\
\cline { 2 - 6 } & Item6 & 3.18 & 1.111 & 148 & Medium \\
\cline { 2 - 6 } & Item7 & 3.70 & 0.869 & 148 & High \\
\cline { 2 - 6 } & Item8 & 3.02 & 0.986 & 148 & Medium \\
\cline { 2 - 6 } & Item9 & 3.43 & 0.874 & 148 & Medium \\
\cline { 2 - 6 } & Item10 & 2.98 & 0.944 & 148 & Medium \\
\hline Motivational CQ & $\mathbf{5}$ & $\mathbf{4 . 0 4 2}$ & & $\mathbf{1 4 8}$ & High \\
\hline
\end{tabular}


Aihemaituoheti Wujiabudula, Çiğdem Karatepe

A STUDY OF PRE-SERVICE ELT TEACHERS' CULTURAL INTELLIGENCE AND ITS RELATIONSHIP WITH

METACOGNITIVE, COGNITIVE, MOTIVATIONAL, AND BEHAVIORAL CULTURAL INTELLIGENCE

\begin{tabular}{|l|l|c|c|c|c|}
\hline \hline \multirow{5}{*}{} & Item11 & 4.46 & 0.741 & 148 & High \\
\cline { 2 - 6 } & Item12 & 4.07 & 0.809 & 148 & High \\
\cline { 2 - 6 } & Item13 & 3.95 & 0.852 & 148 & High \\
\cline { 2 - 6 } & Item14 & 3.86 & 0.911 & 148 & High \\
\cline { 2 - 6 } & Item15 & 3.87 & 0.859 & 148 & High \\
\hline \multirow{5}{*}{ Behavioural CQ } & $\mathbf{5}$ & $\mathbf{3 . 8 3 2}$ & & $\mathbf{1 4 8}$ & High \\
\cline { 2 - 6 } & Item16 & 3.89 & 0.892 & 148 & High \\
\cline { 2 - 6 } & Item17 & 3.72 & 0.889 & 148 & High \\
\cline { 2 - 6 } & Item18 & 3.86 & 0.808 & 148 & High \\
\cline { 2 - 6 } & Item19 & 3.79 & 0.957 & 148 & High \\
\cline { 2 - 6 } & Item20 & 3.90 & 0.902 & 148 & High \\
\hline
\end{tabular}

Table 7: Pre-service ELT Teachers' Degrees of Cultural Intelligence

\begin{tabular}{|l|l|c|c|}
\hline \multirow{2}{*}{ Degree } & \multirow{2}{*}{ Rating } & \multicolumn{2}{|c|}{ Pre-service ELT Teachers' Cultural Intelligence } \\
\cline { 3 - 4 } & & Frequency & $\mathbf{( \% )}$ \\
\hline High & Between 5 and 3.68 & 15 & $75.00 \%$ \\
\hline Medium & Between 3.67 and 2.34 & 5 & $25.00 \%$ \\
\hline Low & Between 2.33 and 1 & 0 & $0.00 \%$ \\
\hline Total & & 20 & $100 \%$ \\
\hline
\end{tabular}

Table 8: Pre-service ELT Teachers' Cultural Intelligence in terms of their Overseas Experience

\begin{tabular}{|l|c|c|c|c|c|}
\hline Overseas Experience & & N & Mean Rank & Sum of Ranks & Total \\
\hline \multirow{2}{*}{ Total } & Yes & 64 & 83.16 & 5322.50 & \\
\cline { 2 - 6 } & No & 84 & 67.90 & 5703.50 & \\
\hline Mann-Whitney U test & & & & & 2133.500 \\
\hline Wilcoxon W & & & & & 5703.500 \\
\hline Z & & & & & -2.146 \\
\hline Asymp. Sig. (2-tailed) & & & & & $0.032^{*}$ \\
\hline
\end{tabular}

Sig. $<0.05$

In order to examine whether the pre-service ELT teachers' cultural intelligence showed any statistical difference in terms of participants' overseas experience, the Mann-Whitney $\mathrm{U}$ test was conducted since the data were not normally distributed.

Table 8 shows participants' CQ in terms of their overseas experience. It can be reported that the pre-service ELT teachers' overseas experience resulted in a statistically significant difference in CQ (Sig. < 0.05). The table indicates that overseas experience was one of the contributing factors for the ELT students' CQ. Even though the number of participants having no overseas experience was higher in the study, those with experience of traveling out of the country produced a higher mean rank $(M=83.16)$ compared to those who had no experience $(\mathrm{M}=67.90)$.

Table 9 illustrates changes in our participants' CQ changing with their age. The results show no statistical difference (Sig. $>0.05$ ) even though the age group $30+$ age group produced the highest mean rank $(\mathrm{M}=82.83)$ compared to the younger age groups. However, age appears to be a differentiating factor according to the student teachers' metacognitive CQ which shows, as the Kruskal-Wallis T-test suggests, that there is a significant difference between age groups (Sig. < 0.05). This result suggested that ELT 
teachers whose ages ranged from 18 to 23 demonstrated the highest mean in terms of their metacognitive CQ $(M=78.48)$. Participants aged 30+ demonstrated the second highest mean $(M=57.08)$, and the lowest mean rank can be seen in participants who were under $18(\mathrm{M}=48.67)$.

To track down whether there was a statistically significant difference in our students' CQ in terms of their self-perceived proficiency level in English, the KruskalWallis T-test was conducted, because the collected data showed a non-normal distribution. According to Table 10, it can be reported that the ELT students' perceived proficiency in English was a contributing factor for increasing the CQ level, since the Kruskal-Wallis Test results showed a meaningful, significant difference among intermediate, upper-intermediate and advanced level speakers. The highest CQ can be seen in intermediate proficient participants $(M=86.25)$, and the second-highest mean was found in advanced proficient participants $(\mathrm{M}=84.37)$, followed by upper-intermediate proficient speakers $(\mathrm{M}=63.88)$.

Table 9: Pre-service ELT Teachers' Cultural Intelligence in terms of Age

\begin{tabular}{|c|c|c|c|c|c|c|}
\hline Factors & Age & $\mathbf{N}$ & Mean Rank & Chi-Square & Df. & Asymp. Sig. \\
\hline \multirow[t]{5}{*}{ Metacognitive CQ } & Under 18 & 3 & 48.67 & & & \\
\hline & $18-23$ & 127 & 78.48 & & & \\
\hline & $24-29$ & 12 & 47.58 & & & \\
\hline & 30 and over & 6 & 57.08 & & & \\
\hline & Total & 148 & & 8.092 & 3 & $0.044^{*}$ \\
\hline \multirow[t]{5}{*}{ Cognitive CQ } & Under 18 & 3 & 70.33 & & & \\
\hline & $18-23$ & 127 & 74.76 & & & \\
\hline & $24-29$ & 12 & 65.63 & & & \\
\hline & 30 and over & 6 & 88.75 & & & \\
\hline & Total & 148 & & 1.221 & 3 & .748 \\
\hline \multirow[t]{5}{*}{ Motivational CQ } & Under 18 & 3 & 44.33 & & & \\
\hline & $18-23$ & 127 & 76.72 & & & \\
\hline & $24-29$ & 12 & 62.46 & & & \\
\hline & 30 and over & 6 & 6 & & & \\
\hline & Total & 148 & & 3.022 & 3 & 0.338 \\
\hline \multirow[t]{5}{*}{ Behavioral CQ } & Under 18 & 3 & 63.33 & & & \\
\hline & $18-23$ & 127 & 75.09 & & & \\
\hline & $24-29$ & 12 & 65.46 & & & \\
\hline & 30 and over & 6 & 85.67 & & & \\
\hline & Total & 148 & & 1.217 & 3 & 0.749 \\
\hline \multirow[t]{5}{*}{ Cultural Intelligence } & Under 18 & 3 & 55.00 & & & \\
\hline & $18-23$ & 127 & 76.53 & & & \\
\hline & $24-29$ & 12 & 53.75 & & & \\
\hline & 30 and over & 6 & 82.83 & & & \\
\hline & Total & 148 & 55.00 & 3.951 & 3 & 0.267 \\
\hline
\end{tabular}

Sig. $<0.05$

It can also be reported that the findings showed a significant difference among participants' metacognitive CQ (Sig. < 0.05) and behavioral CQ (Sig. < 0.05) and cultural 
intelligence as a whole (Sig. <0.05). However, pre-service ELT teachers' cognitive CQ failed to show any statistically significant difference in terms of their perceived proficiency in English (Sig.> 0.05).

When it comes to the pre-service ELT teachers' CQ in terms of their gender, native tongue, university grade, and years of the learning experience, no statistically significant difference was found either in terms of the whole CQ scale or in terms of its dimensions. However, it is worth mentioning that, first of all, male participants' mean score ( $M=79.58)$ in $C Q$ was higher than that of the female participants $(M=71.66)$ even though it showed statistically no difference between gender variables (Sig. > 0.05).

Secondly, it is interesting to note that non-Turkish speaking pre-service ELT teachers' mean score $(\mathrm{M}=82.32)$ in cultural intelligence was higher than Turkish-speaking pre-service ELT teachers' mean score $(\mathrm{M}=73.35)$. However, it failed to show any statistically significant difference in cultural intelligence (Sig. > 0.05).

Thirdly, years of learning English also did not show any statistically significant difference (Sig. > 0.05). However, it can be reported that the mean score increased with the number of years spent learning English. From the Kruskal-Wallis Test, it can be said that participants with 13 and more years' experience of learning English experience had the highest mean scores not only in the whole scale CQ but also in the factors of cultural intelligence.

Table 10: Pre-service ELT teachers' Cultural Intelligence in terms of Proficiency in English

\begin{tabular}{|c|c|c|c|c|c|c|}
\hline Factors & Age & $\mathbf{N}$ & Mean Rank & Chi-Square & Df. & Asymp. Sig. \\
\hline \multirow[t]{4}{*}{ Metacognitive CQ } & Intermediate & 8 & 65.94 & & & \\
\hline & Upper-Intermediate & 72 & 66.44 & & & \\
\hline & Advanced & 68 & 84.04 & & & \\
\hline & Total & 148 & & 6.386 & 2 & $0.041^{*}$ \\
\hline \multirow[t]{4}{*}{ Cognitive CQ } & Intermediate & 8 & 95.38 & & & \\
\hline & Upper-Intermediate & 72 & 72.40 & & & \\
\hline & Advanced & 68 & 74.27 & & & \\
\hline & Total & 148 & & 2.090 & 2 & 0.352 \\
\hline \multirow[t]{4}{*}{ Motivational CQ } & Intermediate & 8 & 61.81 & & & \\
\hline & Upper-Intermediate & 72 & 67.97 & & & \\
\hline & Advanced & 68 & 82.90 & & & \\
\hline & Total & 148 & & 5.057 & 2 & 0.080 \\
\hline \multirow[t]{4}{*}{ Behavioral CQ } & Intermediate & 8 & 86.75 & & & \\
\hline & Upper-Intermediate & 72 & 64.99 & & & \\
\hline & Advanced & 68 & 83.13 & & & \\
\hline & Total & 148 & & 7.234 & 2 & $0.027^{*}$ \\
\hline \multirow[t]{4}{*}{ CQ } & Intermediate & 8 & 86.25 & & & \\
\hline & Upper-Intermediate & 72 & 63.88 & & & \\
\hline & Advanced & 68 & 84.37 & & & \\
\hline & Total & 148 & & 8.386 & 2 & $0.013^{*}$ \\
\hline
\end{tabular}

Sig. $<0.05$. 
Table 11 shows the correlation between CQ and its factors, namely, metacognitive CQ, cognitive CQ, motivational CQ, and behavioral CQ. As can be seen in Table 11, the highest correlations were found in the relationships between $C Q$, and the cognitive , behavioral and motivational CQ dimensions. It can be seen from the correlation coefficient values that the relationship between CQ and motivational CQ was 0.701 (Sig. $<0.05$ ). Therefore, the correlation between CQ and motivational CQ was positive and statistically significant. The correlation coefficients between CQ and behavioral and cognitive CQs were 0.773 and 0.732 , respectively, and both behavioral and cognitive CQ were positively correlated with CQ (Sig. < 0.05). The relationship between CQ and metacognitive CQ was also positive, and the coefficient value was 0.536 (Sig. $<0.05$ ).

Table 11: Correlation of Cultural Intelligence and its Factors

\begin{tabular}{|c|c|c|c|c|c|c|}
\hline & & CQ & MetacogCQ & $\operatorname{Cog} C Q$ & MotiCQ & BehaCQ \\
\hline \multirow[t]{5}{*}{ CQ } & Pearson Correlation & 1 & & & & \\
\hline & Sig. (2-tailed) & & & & & \\
\hline & $\begin{array}{l}\text { Sum of Squares and } \\
\text { Cross-products }\end{array}$ & 12168.777 & & & & \\
\hline & Covariance & 82.781 & & & & \\
\hline & $\mathrm{N}$ & 148 & & & & \\
\hline \multirow[t]{5}{*}{ Metacognitive CQ } & Pearson Correlation & $.536^{* *}$ & 1 & & & \\
\hline & Sig. (2-tailed) & .000 & & & & \\
\hline & $\begin{array}{l}\text { Sum of Squares and } \\
\text { Cross-products }\end{array}$ & 1705.500 & 831.000 & & & \\
\hline & Covariance & 11.602 & 5.653 & & & \\
\hline & $\mathrm{N}$ & 148 & 148 & & & \\
\hline \multirow[t]{5}{*}{ Cognitive CQ } & Pearson Correlation & $.732^{* *}$ & .089 & 1 & & \\
\hline & Sig. (2-tailed) & .000 & .284 & & & \\
\hline & $\begin{array}{l}\text { Sum of Squares and } \\
\text { Cross-products }\end{array}$ & 3935.399 & 124.500 & 2377.318 & & \\
\hline & Covariance & 26.771 & .847 & 16.172 & & \\
\hline & $\mathrm{N}$ & 148 & 148 & 148 & & \\
\hline \multirow[t]{5}{*}{ Motivation CQ } & Pearson Correlation & $.701^{* *}$ & $.405^{* *}$ & $.276^{* *}$ & 1 & \\
\hline & Sig. (2-tailed) & .000 & .000 & .001 & & \\
\hline & $\begin{array}{l}\text { Sum of Squares and } \\
\text { Cross-products }\end{array}$ & 2859.595 & 432.000 & 498.270 & 1367.081 & \\
\hline & Covariance & 19.453 & 2.939 & 3.390 & 9.300 & \\
\hline & $\mathrm{N}$ & 148 & 148 & 148 & 148 & \\
\hline \multirow[t]{5}{*}{ Behavioural CQ } & Pearson Correlation & $.773^{* *}$ & $.256^{* *}$ & $.446^{* *}$ & $.353^{* *+}$ & 1 \\
\hline & Sig. (2-tailed) & .000 & .002 & .000 & .000 & \\
\hline & $\begin{array}{l}\text { Sum of Squares and } \\
\text { Cross-products }\end{array}$ & 3668.284 & 318.000 & 935.311 & 562.243 & 1852.730 \\
\hline & Covariance & 24.954 & 2.163 & 6.363 & 3.825 & 12.604 \\
\hline & $\mathrm{N}$ & 148 & 148 & 148 & 148 & 148 \\
\hline
\end{tabular}

**. Correlation is significant at the 0.01 level (2-tailed). 


\section{Discussion}

The primary purpose of the current study was to elicit the level of the participating preservice ELT teachers' cultural intelligence (CQ) and to find out the relationship between Cultural Intelligence and its sub-factors. To this end, first of all, participants' CQ was examined, and specific appropriate statistical tests were performed to investigate whether their CQ differed in terms of their age, gender, proficiency in English, overseas experience, and their university grade.

In order to answer the questions presented earlier, a reliability test, a test of normality, descriptive statistics, Mann-Whitney U test, and Kruskal-Wallis Tests were conducted through SPSS 24 software program. Second, factor analysis, and multiple correlation analysis was performed to find out the relationships between $C Q$ and metacognitive intelligence, cognitive intelligence, motivational intelligence, and behavioural intelligence.

The results indicated that the pre-service ELT teachers' CQ was comparatively high. The statistical analysis revealed that almost $75 \%$ of participants demonstrated a higher level of agreement towards their CQ. A medium level of agreement was seen in only $25 \%$ of participants' CQ. There was no low level of CQ among participants. The results indicate that the participants' cultural intelligence was at a higher level of agreement than in most sample populations. These research results are in agreement with the most of the research conducted in the literature (Rustambekov \& Mohan, 2017; Dwyer \& Mary, 2004; Dwyer, Mary, \& Courtney K. Peters, 2004; Holoviak, Verney, Winter, \& Holoviak, 2019; Barkley, 2009; Gmelch, 1997; Williams \& Best, 2014; McCrea \& Z. Yin, 2012).

Our participants' CQ showed a statistically significant difference in terms of their travel experience. Those pre-service ELT teachers who had experience of traveling abroad experience showed a higher CQ $(M=83.16)$ than those who had not travelled. Also, these research findings are inconsistent with the studies conducted earlier in the literature (Dwyer \& Mary, 2004; Dwyer, Mary, \& Courtney K. Peters, 2004; Holoviak, Verney, Winter, \& Holoviak, 2019; Barkley, 2009; Gmelch, 1997; Williams \& Best, 2014; McCrea \& Z. Yin, 2012; Morrel, Ravil, Ramsey, \& Ward, 2013). This research, as mentioned above, also found a significant positive relationship between traveling abroad and the individuals' cultural intelligence.

The study looked at the impact of the participants' age on their CQ. It was found that their metacognitive cultural intelligence showed statistically significant (Sig. < 0.05) differences according to their age. However, their cognitive, behavioural, and motivational intelligence showed no statistical differences in terms of their age. The whole CQ scale showed no variation according to their age.

Proficiency was also found to be one of the main contributing factors for the participants' CQ. Their proficiency showed a statistically significant difference in terms of their behavioural (Sig < 0.027), cognitive (Sig < 0.352), and metacognitive (Sig < 0.041) $\mathrm{CQ}$ levels, whereas motivational cultural intelligence showed no difference concerning 
participants' proficiency (Sig. $<0.352$ ). The most important finding was that the whole scale of CQ was also found to be statistically significant in terms of participants' proficiency (Taguchi, 2007; Robledo et al., 2016; Ghonsooly \& Sistani, 2015; Ghonsooly \& Shalchy, 2013). Many studies found in the literature also revealed that having a higher level of proficiency yielded a higher level of cultural intelligence.

Participants' CQ showed no difference according to their gender. However, male pre-service ELT teachers' CQ mean score $(\mathrm{M}=79.58)$ was seen to be higher than that of female student ELT teachers $(\mathrm{M}=71.66)$. The native language appeared to show no significant difference concerning the participants' CQ. However, it was seen that nonTurkish language speakers' CQ mean score $(M=82.33)$ was higher than that of Turkish language speakers. Many studies in the literature also suggested that there was no statistically significant difference in terms of participants' gender (Khodaday \& Ghahari, 2012; Aziz, Fatemi, Pishghadam, \& Ghapanchi, 2015).

The participants' university grade also showed no statistical relation with their CQ. However, the senior participants' CQ mean score was found to be higher than that of younger participants.

Years of learning English is also another factor which showed no statistical difference in terms of participants' CQ. However, the mean score of participants with more experience of learning English experience was higher than that of the participants with less experience of learning English. Regarding the relationship between CQ and metacognitive $C Q$, cognitive $C Q$, motivational $C Q$, and behavioural $C Q$, it can be concluded that $\mathrm{CQ}$ had positive and significant correlations with its sub-factors. The highest correlation coefficients were between CQ and behavioural cultural intelligence $(\mathrm{r}=0.773)$, and cognitive intelligence $(\mathrm{r}=0.732)$. The correlations between CQ and motivational intelligence $(r=0.701)$, and metacognitive intelligence $(r=0.536)$ were also positive. To sum up, all factors of cultural intelligence and cultural intelligence scale were found to be positively correlated with the cultural intelligence in this research.

\section{Conclusion}

The main aim of the study was to elicit the pre-service ELT teachers' levels of cultural intelligence and to study its relationship with metacognitive, cognitive, motivational, and behavioral cultural intelligence.

By way of a conclusion, it can be reported that the study found that the pre-service ELT teachers showed a high level of cultural intelligence. Moreover, it also suggested that participants' cultural intelligence showed a statistically significant difference in terms of proficiency and overseas experience. However, no significant statistical significance was found relating to the participants' age, gender, years of learning English experience, university grade, and participants' native tongue. It was also found that cultural intelligence and its four factors were positively correlated in this current research.

The current research can be used to illustrate several points in teacher education. First of all, overseas traveling or international exchange programs should be considered 
essential for enhancing pre-service ELT teachers' cultural intelligence. The more the preservice ELT teachers obtained international experience, the greater the cultural intelligence that they demonstrated. Secondly, the participants' proficiency levels also showed a statistically meaningful difference. The more proficient the ELT students were, the higher level of cultural intelligence they showed. In terms of participants' age, no statistically significant difference was found; however, the older the participants were, the higher the level of metacognitive cultural intelligence that they showed. Lastly, it is also important to note that the level of cognitive cultural intelligence was found to be considerably lower than the levels of metacognitive, motivational, and behavioral cultural intelligence. Therefore, it can be suggested that academicians working in ELT departments might produce more cognitive cultural intelligence-oriented lesson materials to improve pre-service ELT teachers' complete cultural intelligence.

In general, the ELT students' overall cultural intelligence was positively and strongly correlated with their metacognitive, cognitive, motivational, and behavioral cultural intelligence, even though the levels of cognitive cultural intelligence were slightly lower than that of the other three factors. The findings suggest that metacognitive, cognitive, motivational, and behavioral cultural intelligence might be strengthened in order to improve pre-service ELT teachers' overall cultural intelligence.

The limitations of the current research can be related to the fact that there were only 148 participants. Therefore, a greater sampling size could produce more reliable and valid results. Another limitation of the study was that interviews could not be conducted due to the Covid-19 virus and lock down precautions. It is proposed that conducting semi-structured interviews may shed light on why certain variables did not show any statistical difference in terms of participants' cultural intelligence. The author of this study fondly hopes to be able to reappraise this research in the near future, as soon as the pandemic restrictions have been lifted.

\section{Acknowledgements}

This paper and the research behind it would not have been possible without the exceptional support from my teacher Dr. Çiğdem Karatepe. Her knowledge, enthusiasm, knowledge and exacting attention to detail have been an inspiration and kept my work on track from the start of my MA program. My former colleague and fellow English instructor, Wendy Hibbis, looked over the research paper and provided exceptional assistance for proofreading the paper, and I once again send my great thanks to my dear colleague Wendy Hibbis for her great help.

\section{About the Authors}

Asst. Prof. Dr. Çiğdem Karatepe is Assistant Professor of English Language Department of English Language at University Bursa Uludağ University in the city of Bursa, Turkey. She graduated from the Middle East Technical University English Language Education in 1990. In 1991 she won a scholarship from the Turkish National Ministry of Education. Between 1991-1998, she completed her MA and PhD studies at the University of 
Liverpool in England. Her areas of interest are pragmatics, teaching speech acts, intercultural communication, intercultural sensitivity, cultural intelligence and language acquisition.

Aihemaituoheti Wujiabudula graduated from Xinjiang University of Finance and Economics, Department of English in 2011. In 2016, he completed his MSc. In Business Administration from Yildiz Technical University. He also gained MA degree in English Language Education from Uludag University in 2019. He has been working at Uskudar University, Department of Foreign Languages as an academic English instructor since 2019.

\section{References}

Ang, S., \& Van Dyne, L. (2008). Conceptualization of cultural intelligence: Definitions, distinctiveness, and nomological network. In A. a. Dyne, Handbook of cultural intelligence: Theory, measurement, and applications (pp. 3-15). New York: M.E. Sharpe.

Aziz, Z., Fatemi, A., Pishghadam, R., \& Ghapanchi, Z. (2015, May). Investigating the Relationship between Iranian EFL learners' Cultural Intelligence and their Home Culture Attachment. Mediterranean Journal of Social Science, 6(3), 575-585.

Barkley, E. (2009). Student Engagement Techniques: A handbook for College Faculty. San Francisco, CA.

Brislin, R. (1981). Cross-cultural encounters: Face-to-face interaction. New York: Pergamon.

Brislin, R., Worthley, R., \& MacNab, B. (2006). Cultural Intelligence: Understanding behaviors that serve people's goals. Group \& Organization Management, 31(1), 4055.

Cameli, A. (2003). The relationship between emotional intelligence and work attitudes, behavior, and outcomes: An examination among senior managers. Journal of Managerial Psychology, 18(8), 788-813.

Crowne, A., \& Engle, R. (2014). The impact of international Experience on cultural intelligence: an application of contact theory in a structured short-term program. Human Resource Development International, 17(1), 30-46.

Dwyer \& Mary. (2004). "More is better: The impact of study abroad program duration." Frontiers: The Interdisciplinary Journal of Study Abroad, 10, 151-163.

Dwyer, Mary, \& Courtney K., P. (2004). The benefits of study abroad. Transitions Abroad, $37(5), 48-66$.

Earley, P., \& Ang, S. (2003). Cultural Intelligence: Individual Interactions across cultures. Palo Alto: Stanford University Press.

Erez, e. (2013). Going Global: Developing management students' cultural intelligence and global identity in culturally diverse virtual teams. Academy of Management Learning E Education, 12(3), 330-335. 
Ghonsooly, B., \& Shalchy, S. (2013). Cultural Intelligence and writing ability: Delving into fluency, accuracy, and complexity. Novitas-Royal (Research on Youth and Language), 7(2), 147-159.

Ghonsooly, B., \& Sistani, S. (2015). Cultural intelligence in foreign language learning contexts. Cultus, 47.

Gmelch, G. (1997). Crossing Culture: Student travel and personal development. International Journal of Intercultural Relations, 21(4), 475-490.

Holoviak, J., Verney, T., Winter, A., \& Holoviak, S. (2019, 12, 17). "Assessing academic performance through study abroad: Benefits of the experience." Retrieved 12 2019, from http://www.aabri.com/manuscripts/10713.pdf

Khodaday, E., \& Ghahari, S. (2012). Exploring the Relationship Between Foreign Language Proficiency and Cultural Intelligence. The International Journal of Language Learning and Applied Linguistics World, 1(1), 22-31.

Kim, Y. (1992). Intercultural Communication Competence: A systems-thinking View. In Gudykunst, \& Y. Kim, Reading on Communicating with Strangers: An Approach to Intercultural Communication (pp. 371-381). New York: McGraw-Hill.

Lee, L.-Y., \& Sukoco, M. (2010). The effect of cultural intelligence on expatriate performance: the moderating effects of international Experience. The international journal of Human Resource Management, 21(7), 963-981.

Markum, J. (2017). Language Proficiency and Cultural Intelligence in Distance EnglishLanguage Learning. Retrieved 12 2019, from Theses and Dissertation 669: http://digitalcommons.usu.edu/etd/6691

McCrea, E., \& Z. Yin, J. (2012). Developing Cultural Intelligence: An Undergraduate Course Assessment Framework. Organizational Management, 9, 104-111.

Morrel, D., Ravil, E., Ramsey, J., \& Ward, A. (2013). Past Experience, cultural intelligence, and satisfaction with international business studies. Journal of Teaching in International Business, 24(1), 31-43.

Rachmawaty, N., Akil, M., \& Dollah, S. (2018). Do Cultural Intelligence and Language Learning Strategies Influence Students' Language Proficiency. Journal of Language Teaching and Research, 9(3), 655-663.

Risager, K. (2006). Language and culture: Global flows and local complexity. Clevedon, England: Multilingual Matters.

Robert, L., E., \& Bariana, N. (2016). Foreign Travel Experience and Cultural Intelligence: Does Country Choice Matter. Journal of Teaching in International Business, 27(1), 2340.

Robledo-Ardila, C., Aguilar-Barrientos, S., \& Roman-Calderon, J. (2016). EducationRelated Factors in Cultural Intelligence Development: A Colombian Study. Journal of Teaching in International Business, 27, 41-58.

Rustambekov, E., \& Mohan, R. (2017). Cultural Immersion Trip to Southeast Asia: A Study of Cross-Cultural Intelligence. Journal of Teaching in International Business, 28(2), 87-103. 
Schmidt, F., \& Hunter, J. (2000). Select on intelligence. In E. Locke, Blackwell handbook of organizational principles (pp. 3-14). Oxford: Blackwell.

Stemberg, R., \& Detterman, D. (1986). What is intelligence? Contemporary viewpoints on its nature and definition. Norwood: NJ: Ablex.

Stemberg, R., Forsythe, G., Hedlund, J., Horvath, J., Wagner, R., \& Williams, W. (2000). Practical intelligence in everyday life. New York: Cambridge University Press.

Taguchi, N. (2007). Development of Speech and Accuracy in Pragmatic Comprehension in English as a Foreign Language. TESOL Quarterly, 313-338.

Thomas, D., \& Inkson, K. (2003). Cultural Intelligence: People Skills for Global Business. San Francisco: CA: Berrett-Koehler.

Thorndike, R., \& Stein, S. (1937). An evaluation of the attempts to measure social intelligence. Psychological Bulletin, 275-285.

Van Dyne, L., \& Ang, J.-S. (2008). The sub-dimensions of the four-factor model of cultural intelligence: Technical Report. Cultural Intelligence Center.

William, T. (2005). Exploring the impact of study abroad on students' intercultural communication skills: adaptability and sensitivity. Journal of Studies in Intercultural Education, 9(4), 356-371.

Wood, E., Heather, Y., \& St. Peters, Y. (2014). Short-term cross-cultural study tours: impact on cultural intelligence. The International Journal of Human Resource Management, 25(4), 558-570. 
Creative Commons licensing terms

Authors will retain the copyright of their published articles agreeing that a Creative Commons Attribution 4.0 International License (CC BY 4.0) terms will be applied to their work. Under the terms of this license, no permission is required from the author(s) or publisher for members of the community to copy, distribute, transmit or adapt the article content, providing a proper, prominent and unambiguous attribution to the authors in a manner that makes clear that the materials are being reused under permission of a Creative Commons License. Views, opinions and conclusions expressed in this research article are views, opinions and conclusions of the author(s). Open Access Publishing Group and European Journal of Applied Linguistics Studies shall not be responsible or answerable for any loss, damage or liability caused in relation to/arising out of conflict of interests, copyright violations and inappropriate or inaccurate use of any kind content related or integrated on the research work. All the published works are meeting the Open Access Publishing requirements and can be freely accessed, shared, modified, distributed and used in educational, commercial and non-commercial purposes under a Creative Commons attribution 4.0 International License (CC BY 4.0). 